\title{
HOCAM KENAN AKYÜZ
}

\section{PROF DR. CAHITT KAVCAR}

Yeni Türk Edebiyatı alanında yurt içi ve yurt dışı bir üne ulaşmış olan Prof. Kenan Akyüz'ü 4 Ocak 1996 günü kaybettik. Edebiyat ve bilim dünyamızın büyük bir değerini öteki dünyaya yolcu ettik. Ve biz öğrencileri, Akyüz hocanın bilgi saçan varlığından yoksunuz şimdi. Çok seçkin bir bilim adamı, titiz bir araştırmacı ve incelemeci, iyi bir yönetici ve çok iyi hocaydı. Ama her şeyden önce gerçek bir yurtsever ve büyük bir aydındı 0 .

Ölenin ardından bir şeyler yazıp söylemek gerçekten güç. Hele bu ölen, Kenan Hoca gibi çok yönlü, değişik mizaçlı ve renkli bir kişilik olunca, onu çok yakından tanıyan biri için bu güçlük daha da artıyor. Kişi söze nereden başlayacağını, onu hangi yönüyle ele alacağını kolay kolay kestiremiyor. Böyle olunca da sözlerde ister istemez bir dağınıklık kendini gösterecektir. Ama ben yine de uzun yıllar öğrencisi olmuş, uzun süre asistan olarak yanında çalışmış ve ona çok şey borçlu bir kişi olarak Hoca'nın bazı yönleri üzerinde durmaya çalıșacağım.

Daha öğretmen okulu yıllarında iken "Batı Tesirinde Türk Şiiri Antolojisi" adlı eseri vasıtasıyla adını çok iyi tanıdığım Akyüz Hoca'yı yüzyüze ilk kez 1960 yılında gördüm. Ankara Yüksek Öğretmen Okulu kanalıyla, lise edebiyat öğretmeni olmak üzere Ankara Üniversitesi Dil ve Tarih-Coğrafya Fakültesi Türk Dili ve Edebiyatı Bölümüne girmiştim. Kenan Bey Kürsü Başkanıydı, ilk iki yıl hocamız olmadı. Yeni Türk Edebiyatı derslerimize rahmetli hocamız Prof. Dr. Gündüz Akıncı giriyordu. Ama koridorda zaman zaman gördüğümüz Kenan Hoca, dimdik yürüyüşü, çok temiz ve çok şık giyinişi, bembeyaz ve her zaman çok iyi taranmış saçları, sert görünüşü, ince bıyığı, pırıl pırıl iskarpinleri, zaman zaman da uzun saplı şemsiyesi ile göze çarpardı. öğrenciler ondan çok çekinir, odasının önünden geçerken korkarlardı.

Son iki yıl bizim de hocamız oldu. Birlikte roman, şiir, tiyatro 
ve edebiyat tarihi dersleri işledik. Çok düzenli ve disiplinli bir hoca idi. Derslere elinde "mavi kaplı bir defter"le gelir, deftere öğrencilerle ilgili notlar yazar, ça1ışma durumuyla ve okunması gereken kitapların okunup okunmadığıyla ilgili işaretler koyardı. Derslerini çok renkli, canlı, öğrenci katkısı ve katılımı ile birlikte, zaman zaman espriler katarak yürütürdü.

Kenan Akyüz Eğitim Fakültesinde de hocalık yapıyordu. 1968 yılında Eğitim Fakültesinde Hocanın asistanı oldum. Yüksek lisans ve doktora derslerimize girdi, doktora tez hocam oldu. Doçentlik çalışmalarım sırasında sürekli yardımını gördüm. Kendisine çok şeyler borçluyum, minnettarım.

İlk bakışta çok sert ve katı görünen Hoca'nın sohbetlerine doyum olmazdı. Başlı başına bir tarihti. Bilgi birikimi ve ilginç anılar bakımından çok zengindi. Onunla her konuda ve rahatça sohbet edebilirdik. Zaman zaman gevrek gevrek gülerdi, onu dinlemek kişiye zevk verirdi.

Yanında ve çevresinde bulunanları içten içe ve derinden etkilerdi. Zaman zaman aşırı alınganlıklar içine girdiği, yakın çevresindekileri kırdığı, kendisinden uzaklaştırdığı ve kendisini bir anlamda yalnızlığa ittiği olurdu.

Kenan Hoca 1970-1972'de iki yıl Eğitim Fakültesi Dekanlığı da yaptı. O sırada Fakültenin akademik ve idarî personel sayısı çok azdı, çok yetersizdi. Bir yandan da 12 Mart öncesi öğrenci olayları çok yaygındı. Hoca Fakültenin personel bakımından gelişmesi ve mezunlarının istihdamı konularında çok önemli hizmetlerde bulundu. Onun bu tür hizmetleri Fakültemizde hâlâ saygıyla anılmaktadır. Kaderde, Hocadan 25 yıl kadar sonra aynı Fakültede dekan olmak varmış. Bundan onur ve gurur duyuyorum.

Hem eskiyi iyi bilmek, hem de yeniyi yakından izlemek. Bu gerçekten güç bir şeydir ve özel bir çaba gerektirir. Hoca'nın her gece düzenli olarak oturup çalıştığını, okuduğunu çok iyi biliyoruz. Yeni Türk Edebiyatı tarihi için anıt eserlerden biri olan ve ilk baskısı 1969 yılında yapılan "Modern Türk Edebiyatının Ana Çizgileri" adlı eseri, çok önemli ve çarpıcı bir giriş bölümünden sonra TanzimatCumhuriyet dönemini ele alıyordu. Cumhuriyet'ten sonraki dönemi de büyük bir titizlikle işledi, 1980'lere kadar getirdi, Türk Ansiklopedisi ile İslâm Ansiklopedisi'nin "Türk Edebiyatı" maddelerinde yayımladı. 
Bu bölüm de ayrı bir kitap hacmindedir. "Batı Tesirinde Türk Şiiri Antolojisi" adlı dev eseri, inceleme ve antoloji olarak alanın en yetkin eserlerinin başında gelir. "Tevfik Fikret" adlı eseri ise, edebiyatımızda monografik eser türünün en çarpıcı ve değerli eserlerinden biridir. Onun daha birçok kitabı, makalesi var.

Kenan Akyüz yok artık. Herkesin bir gün gideceği sonsuzluk ülkesine o da gitti. "Sessiz gemi"ye o da bindi ve bilinmeyen dünyaya göçtü. Evet herkes gidecek ölüm ülkesine. Önemli olan, kişinin geride iyi anılar, dostça duygular, kalıcı izler bırakarak gidebilmesidir. Bu açıdan bakınca Akyüz Hoca'yı mutlu bir insan saymak gerekir. Çünkü hiç de boşuna geçmemiş 85 yıllık bir yaşamı var, pek çok öğrencisi var. Böyle kişilerin yeri kolay kolay doldurulamaz. Değerli Hocamı bir kez daha saygiyla, minnetle anıyorum. 


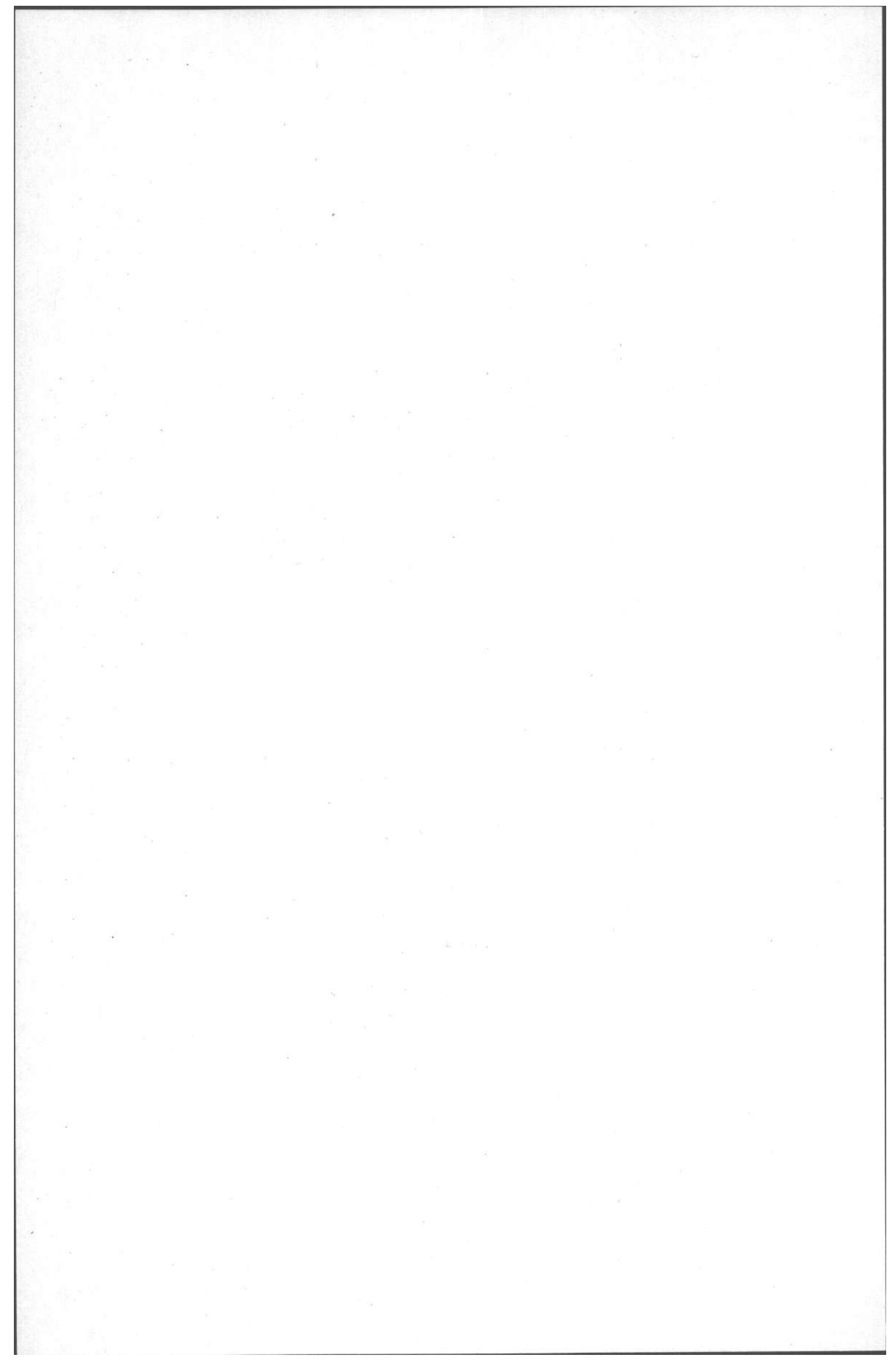

